\title{
Fecal Contamination of Drinking Water within Peri-Urban Households, Lima, Peru
}

\author{
William E. Oswald,* Andrés G. Lescano, Caryn Bern, Maritza M. Calderon, Lilia Cabrera, and Robert H. Gilman \\ Asociación Benéfica Proyectos en Informática, Salud, Medicina, y Agricultura (A.B. PRISMA), Lima, Peru; Universidad Peruana \\ Cayetano Heredia, Lima, Peru; Centers for Disease Control and Prevention, Atlanta, Georgia
}

\begin{abstract}
We assessed fecal contamination of drinking water in households in 2 peri-urban communities of Lima, Peru. We measured Escherichia coli counts in municipal source water and, within households, water from principal storage containers, stored boiled drinking water, and water in a serving cup. Source water was microbiologically clean, but $26(28 \%)$ of 93 samples of water stored for cooking had fecal contamination. Twenty-seven (30\%) of 91 stored boiled drinking water samples grew $E$. coli. Boiled water was more frequently contaminated when served in a drinking cup than when stored $(P<0.01)$. Post-source contamination increased successively through the steps of usage from source water to the point of consumption. Boiling failed to ensure safe drinking water at the point of consumption because of easily contaminated containers and poor domestic hygiene. Hygiene education, better point-of-use treatment and storage options, and in-house water connections are urgently needed.
\end{abstract}

\section{INTRODUCTION}

Contaminated drinking water is a principal cause of the diarrheal disease that results in 2.5 million childhood deaths yearly. ${ }^{1}$ International water-quality standards permit no detectable level of harmful pathogens at the point of distribution. ${ }^{2}$ However, microbiological water quality can deteriorate in the course of collection, transport, and home storage. ${ }^{3-13}$ Thus, access to a safe source alone does not ensure the quality of water that is consumed. Furthermore, a better water source does not lead to full health benefits in the absence of improved water storage and sanitation. ${ }^{14}$ Clearly, point-of-use water quality is a critical public health indicator. ${ }^{15,16}$ Boiling of drinking water is an intervention in the "domestic domain" of infectious disease transmission. Intervention in the "public domain" commonly involves chlorine treatment prior to piped distribution, which provides a residual level of protection from contamination. ${ }^{17}$ To determine the extent of and risk factors for fecal contamination, we examined drinking water quality during the cascade from source to storage to consumption in peri-urban households of Lima, Peru.

\section{METHODS}

Study site. Sampling was carried out from September to November, 2005, in two adjacent pueblos jovenes (shantytowns) of Las Pampas de San Juan de Miraflores, a community on the outskirts of Lima, Peru, described in previous publications. ${ }^{14,18-21}$ Lima is located in a desert that receives < 1 inch of rainfall annually. These shantytowns are perched above the city on a steep and rocky hillside with dusty soil and no natural vegetation. The study communities were selected based on their similarity to other peri-urban communities in Lima and the absence of in-house water connections.

Household selection. The communities were visited Monday through Thursday between 1 and 5 PM, when residents were less busy. Households were included if residents were present on any 1 of 3 visits. Out of 184 households, 75 households were excluded because all inhabitants worked outside the community and only returned late at night or on Sundays.

* Address correspondence to William E. Oswald, A.B. PRISMA, Av. Carlos Gonzales 251, Urb. Maranga, San Miguel, Lima, Peru. E-mail: william.oswald@jhsph.edu
The resident primarily responsible for collecting water was asked to participate and provided informed consent. Of the 109 households that met our inclusion criteria, 16 (15\%) declined to participate. The protocol was approved by the ethics committee of A.B. PRISMA.

In-house stages of water storage and consumption. Households stored water for drinking, cooking, washing clothes, and other uses in containers of varying types and sizes. This first stage was defined as principal water storage. We knew from preliminary data that water was habitually taken from this container, boiled, and then stored in smaller containers for later drinking (stage 2, drinking water storage). If the household did not have boiled drinking water at the time of the visit, a subsequent visit was arranged. The final stage consisted of drinking water served in a cup (stage 3, drinking water consumption).

Sampling methods. The resident was first asked to rinse each hand for 30 seconds in a plastic (Zip-loc) bag containing $100 \mathrm{~mL}$ of distilled water. Five other water samples were collected in $250-\mathrm{mL}$ sterile glass bottles. First, samples from each of the 3 stages described above were collected: 1 ) water from the principal storage container as normally collected by residents; 2) drinking water taken directly from the boiled drinking water container; 3 ) drinking water as served in a cup. Then the resident was asked to wash the cup as they normally would, and 2 additional samples were collected: 4) boiled drinking water, as served in the same cup after it was washed; and 5) the water used to rinse the cup after being washed for sample 4. Samples from shared community water sources were collected separately.

In samples from the principal storage stage and from shared community sources, free active chlorine was measured using the $N, N$-diethylphenylenediamine (DPD) colorimetric method (Hach Company, Loveland, $\mathrm{CO}$ ), and $\mathrm{pH}$ was measured with Panpeha indicator strips (Sigma-Aldrich, Seelze, Germany). Water temperature was measured at each stage with a thermometer. Turbidity was not measured because the source water was free of sediment. To dechlorinate samples, 2 drops of a $3 \%$ sodium thiosulfate $\left(\mathrm{Na}_{2} \mathrm{~S}_{2} \mathrm{O}_{3}\right)$ solution added for each $100 \mathrm{~mL}$ of water. Samples were labeled, coded, placed on icepacks, and protected from light in a sealed cooler.

A cotton swab moistened with sterilized water was passed over the handle or outer surface of the vessel used to obtain cooking water from the principal storage container. A second 
swab was taken from the entire inner surface of an unused drinking cup. These swabs were transported to the laboratory in loosely sealed plastic tubes containing $10 \mathrm{~mL}$ of sterilized water.

A structured 30-minute questionnaire was administered in Spanish, collecting information on the respondent's personal and domestic hygiene practices, water handling and usage, and sociodemographics. At the end of the interview, each household was given an explanation of the results of the chlorine test and a bottle of purified water as a gift for participation.

Laboratory methodology. All water samples were transported to the laboratory at the Peruvian University Cayetano Heredia and processed within 6 hours of sampling using membrane filtration and incubated on $\mathrm{m}$-ColiBlue 24 in accordance with the manufacturer's instructions (Hach Company, Loveland, CO). Escherichia coli colonies per $100 \mathrm{~mL}$ of sample were enumerated based on the number of blue colonies. ${ }^{22}$ One-hundred milliliters of sample were filtered directly, except for the hand- and dish-rinsing samples, for which additional 1:2 and 1:40 dilutions were prepared and filtered.

The tubes with the swabs and solution were agitated, and then the swabs were discarded. One milliliter of the solution was then added to $9 \mathrm{~mL}$ of previously prepared lauryl sulfate broth, which was then incubated at $45^{\circ} \mathrm{C}$ for no more than 24 hours. At that time, if growth had occurred, as shown by gas bubbles and cloudiness, serial dilution was performed to obtain a 1:10 ${ }^{6}$ dilution, of which $0.1 \mathrm{~mL}$ was inoculated on EMB agar and incubated at $37^{\circ} \mathrm{C}$ for no more than 24 hours. After incubation, colonies with a metallic green color were counted. ${ }^{23,24}$

Statistical analysis. Multivariable logistic regression analyses were performed to examine factors associated with fecal contamination of water samples at each of the 3 stages (principal storage, drinking water storage, and drinking water consumption). Water quality was measured by a binary variable indicating whether any E. coli was detected. This measure was chosen instead of a continuous scale due to the frequency of E. coli "too numerous to count." We examined potential risk factors based on specific container characteristics: type; size; large opening; storage location; covered storage; and access of children and animals. A number of exploratory covariates measured hygiene practices related to the water vessels at each stage: time since washing of vessel; form of washing; frequency of washing; and whether the drinking cup was wet or dry at the time of sampling. Measures of water temperature, ambient temperature and humidity, and free active chlorine at the principal storage stage examined possible influences on the survival of bacteria. Boiling was assumed to remove any residual chlorine, so it was not tested at subsequent stages. The source of water, whether from a neighbor's connection or the community standpipe, was examined at the principal storage stage. Whether the stored drinking water had been prepared as tea and the time since boiling, as a proxy variable for temperature, were included at the drinking water storage stage. Finally, the household sanitary and socioeconomic conditions were measured by the following variables: toilet type; family size; reported monthly household income; education of household head; and property ownership. All continuous variables were categorized in tertiles, and contiguous tertiles were aggregated post hoc if they had comparable frequencies of contamination. Binomial family, logis- tic link generalized linear models were used to calculate the odds ratios for $E$. coli contamination in univariate analyses and multivariable logistic regression models. Multivariable logistic regression models were built using a manual forward stepwise approach. The most significant covariates, based on the results of likelihood-ratio tests, were sequentially added to the model.

Finally, the Wilcoxon matched-pairs signed-ranks test was used to compare intrahousehold paired continuous $E$. coli counts between stages (i.e., E. coli counts in principal storage container versus boiled drinking water storage and drinking water storage versus consumption, within the same household). Observations from households where samples from both stages were "too numerous to count" were not included in this analysis because it was impossible to determine if the concentration of $E$. coli had increased, decreased, or remained the same. ${ }^{7}$ If only 1 of the matched samples was "too numerous to count," then it was given the value of the upper limit of the dilution (e.g., 200 if directly filtered). Data from all 93 houses are presented unless otherwise noted. All analyses were performed with Intercooled Stata 8.2 (StataCorp LP, College Station, TX).

\section{RESULTS}

Household characteristics. Of 93 participants, 63 (68\%) owned their houses and 22 (24\%) were living on property without a land title. Families had lived in their houses a median of 8 years (range, 2 weeks to 23 years). Families reported earning a mean of US $\$ 132$ per month, and household heads had a mean of 9 years of education. Sampling took place during the spring when the mean daily temperature was $18.0^{\circ} \mathrm{C}$ and mean absolute humidity was $14.7 \mathrm{~g} / \mathrm{m}^{3}$. Sixty-three households (68\%) used pit-latrines, and 30 households $(32 \%)$ had sewage connections.

Water collection. No study household had an in-house water connection. All water was bought from nearby households with water connections $(82 \%)$ or collected from a shared standpipe $(18 \%)$. Both of these outlets provided water from the same high-quality source. Two samples taken 1 month apart from the standpipe had chlorine residuals of 0.7 and 0.5 $\mathrm{mg} / \mathrm{L}$, and samples from each of the 2 houses where other participants reported buying water had residuals of 0.6 and $0.5 \mathrm{mg} / \mathrm{L}$. All source water samples were negative for fecal contamination. All families without a connection used hoses to channel water from the source outlet directly to storage containers in their homes.

Principal water storage. Of 93 households, 39 (42\%) used large cisterns made of cement and brick or prefabricated plastic tanks, and $41(44 \%)$ used barrels of metal or plastic to store water (Table 1$)$. The median reported time since filling was 3 days but ranged from 2 hours to 1 month. Water temperature ranged from 16 to $25.5^{\circ} \mathrm{C}$, and, of 89 samples, all had a neutral $\mathrm{pH}$ of 7 . Of 92 water samples, 32 (35\%) had no free active chlorine residual and $44(48 \%)$ had $<0.2 \mathrm{mg} / \mathrm{L}$. A negative correlation was found between the chlorine residual and the days since filling (Spearman $\rho=-0.526, P<0.01$ ).

E. coli was detected in $26(28 \%)$ of 93 samples from principal water storage (Figure 1). Multivariable logistic regression revealed that the amount of chlorine residual and water temperature were the most significant predictors of fecal contamination (Table 2). Compared with water with no chlorine 
TABLE 1

Escherichia coli contamination by container type used for principal and drinking water storage in households in a peri-urban community of Lima, Peru

\begin{tabular}{lrc}
\hline \multicolumn{1}{c}{$\begin{array}{c}\text { Containers used by } \\
\text { water storage stage }\end{array}$} & $n$ & $\begin{array}{c}\text { Contaminated } \\
n(\%)\end{array}$ \\
\hline Principal water storage & & \\
Cistern/tank & 39 & $8(21)$ \\
Barrel & 41 & $12(29)$ \\
Bucket/basin & 8 & $6(75)$ \\
Jerrycan & 5 & $0(0)$ \\
Total & 93 & $26(28)$ \\
Drinking water storage & & \\
Kettle & 27 & $2(7)$ \\
Pitcher & 39 & $19(49)$ \\
Thermos & 9 & $0(0)$ \\
Bottle & 4 & $2(50)$ \\
Saucepan & 7 & $1(14)$ \\
Bowl & 5 & $3(60)$ \\
Total & 91 & $27(30)$ \\
\hline
\end{tabular}

residual, water with any residual chlorine was less frequently contaminated, and higher water temperatures reduced the odds of contamination.

Twelve (13\%) of 93 swabs of the outer surfaces and handles of pitchers and other vessels used to collect water for cooking recovered a geometric mean of $25 \mathrm{E}$. coli $\mathrm{cfu} / \mathrm{mL}$ (range, $1-243)$.

Drinking water storage. All but 1 of the 93 study households reported that they normally boiled their drinking water. The 1 household that did not boil drinking water reported that this was due to the cost of kerosene. In 1 other household, boiled water was not available for testing because it had been used to prepare lemonade. Of the 91 remaining households, 39 (43\%) used pitchers and 27 (30\%) used kettles for storage after boiling (Table 1). Water sample temperature ranged from 17.5 to $58^{\circ} \mathrm{C}$. The median time since boiling was 7 hours, but ranged from $<1$ to $>31$ hours. Twenty-seven (30\%) samples were contaminated with E. coli (Figure 1). In multivariable logistic regression models, boiled water not stored in a kettle was almost 8 times as likely to be contaminated, and water temperature $\geq 30^{\circ} \mathrm{C}$ was associated with a lower risk of contamination (Table 2).

No difference in quality was detected between principal storage container water and stored boiled drinking water ( $N=85, P=0.16)$. However, in the 54 houses where the principal stored water had detectable free active chlorine, the stored boiled drinking water was significantly more contaminated (Table 3 ). In the houses where no free active chlorine remained in principal stored water, no significant difference was detected between this water and boiled drinking water $(P=0.78)$.

Drinking water at the point of consumption. In 32 (39\%) of 83 households, boiled drinking water was more contaminated when served in a cup than when taken directly from the storage container, with a significant increase in $E$. coli counts between these 2 stages $(P<0.01)$. Drinking cup contamination was assessed in the 64 houses with uncontaminated boiled drinking water. In 23 (36\%) of these, the boiled water as served in a cup grew E. coli. Cups that were moist or wet prior to sampling carried a higher risk than dry cups, whereas water temperature $>40^{\circ} \mathrm{C}$ and cup storage in a closed container lowered contamination risk (Table 2$)$. Twelve $(13 \%)$ of
93 swabs from drinking cup inner surfaces grew a geometric mean of 30 E. coli $\mathrm{cfu} / \mathrm{mL}$ (range, 3-300).

Domestic and personal hygiene. When asked how the cup was washed before serving water, 75 (82\%) of 92 respondents reported using clean water to rinse the cup; the remainder rinsed the cup in "used" water. Eighty-nine (97\%) of 92 respondents used detergent, and $80(91 \%)$ of 88 respondents washed with a sponge instead of their hands. All respondents used "new" water for the final rinse. No one reported using hot water. Only 10 (11\%) of 92 respondents used a towel to dry after washing.

A total of 64 water samples used for the final cup rinse were collected. Of these, 51 samples $(80 \%)$ grew a geometric mean of $2.00 \times 10^{3} E$. coli $\mathrm{cfu} / 100 \mathrm{~mL}$ (range, $5>8,000$ ). There was no significant difference in $E$. coli counts in the boiled water from each drinking cup before and after washing $(P=0.75)$.

One-minute rinses of respondents' hands revealed extensive fecal contamination: 85 (91\%) of 93 hand-rinse samples were positive with a geometric mean of $177 \mathrm{E}$. coli $\mathrm{cfu} / 100 \mathrm{~mL}$ (range, $2>8,000$ ). Hand-rinse colony counts were positively correlated with cup rinse-water colony counts in the same household (Spearman $\rho=0.27, P=0.03$ ).

\section{DISCUSSION}

Despite clean, adequately chlorinated source water and the widespread practice of boiling water for drinking, we found that contaminated water is consumed with remarkable frequency in these peri-urban communities. Fecal contamination increased as we followed the water from its source to drinking water storage containers and then into the cups used to serve the water. In comparisons of health impacts due to source water and household-level interventions, such postsource contamination has been shown to increase diarrhea risk. ${ }^{25}$ Our data detected no relationship between water quality at any stage and the household's form of excreta disposal, perhaps because community-wide sanitation changes would be necessary to effect a significant change. Fecal pathogens on both hands and household utensils appeared to contribute to point-of-use contamination, highlighting the need for improved personal and domestic hygiene practices. Ideally, inhouse water connections would provide chlorinated water directly from the tap to the drinker (or cup washer), eliminating the need for storage. However, as long as water storage remains a fact of life in communities like these, interim measures will be needed to address these risks.

Our data suggest strongly that the major sources of contamination resulted from poor water storage and hygiene practices in the home. Households gathered water with low but adequate amounts of free chlorine and no fecal contamination. ${ }^{2}$ Introduction of fecal contamination during transport was minimal in this community. ${ }^{10,15,26}$ Instead of carrying water in buckets or other containers, all study households used long hoses to route water directly from a standpipe or neighbor's spigot to household storage containers. This practice likely developed as a much easier way to collect water in the steep, rocky conditions of this community.

The absence of free active chlorine was the most significant determinant of fecal contamination at the first stage, the principal storage water container. Characteristics such as a spigot or narrow mouth reduce the rate at which chlorine volatilizes 


\section{In-House Stages of Water Storage and Consumption:}

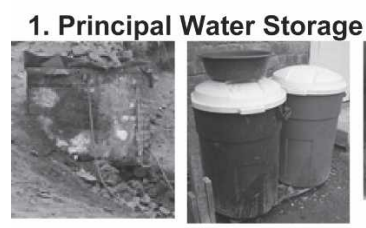

2. Drinking Water Storage
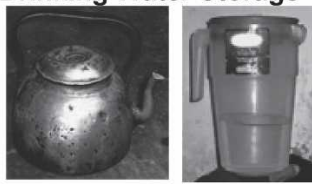

3. Drinking Water Consumption

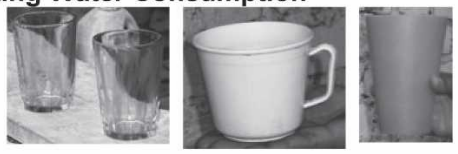

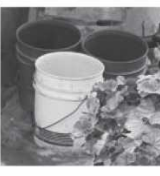

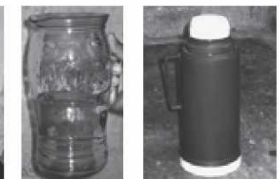

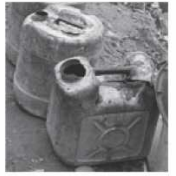
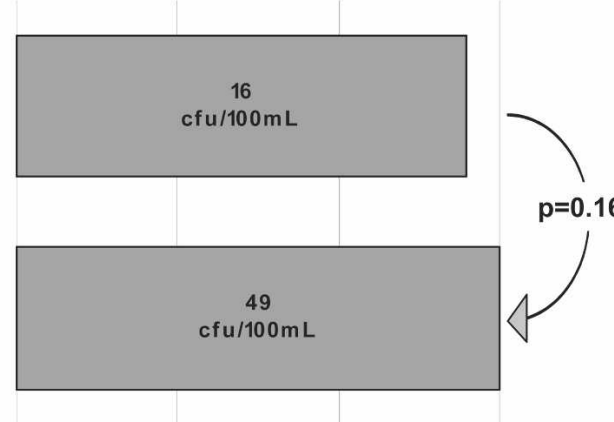

$p=0.16$
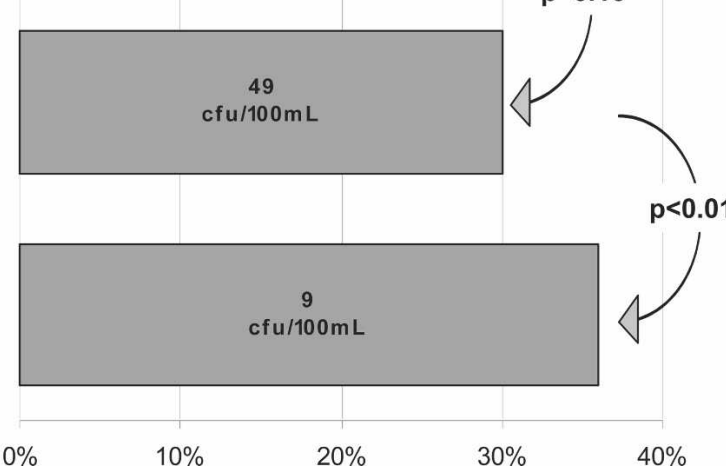

FIGURE 1. Stages of storage and consumption and examples of some vessels used within peri-urban households of Lima, Peru, alongside the geometric means and percentages of water samples positive for Escherichia coli ( $P$ values from Wilcoxon signed-ranks tests for matched in-house changes in E. coli colony counts between stages).

from water. ${ }^{27}$ Not surprisingly, we detected lower free chlorine levels in water stored for a longer time. ${ }^{10}$ In addition, longer storage time implies more opportunity for contamination, because hands and the handle or outer surface of col-

TABLE 2

Multivariable logistic regression models for the presence of Escherichia coli in samples of water from storage to consumption in households in a peri-urban community of Lima, Peru

\begin{tabular}{|c|c|c|c|}
\hline Model for each stage & $\begin{array}{l}\% \text { of } \\
\text { Samples }\end{array}$ & Odds ratio & $P$ \\
\hline \multicolumn{4}{|c|}{ Model 1. Principal water storage $(n=93)$} \\
\hline \multicolumn{4}{|l|}{ Chlorine residual } \\
\hline$\geq 0.04 \mathrm{mg} / \mathrm{L}$ & 42 & $0.02(<0.01,0.14)$ & $<0.01$ \\
\hline $0.01-0.03 \mathrm{mg} / \mathrm{L}$ & 24 & $0.26(0.07,0.94)$ & 0.04 \\
\hline None & 34 & Referent & - \\
\hline \multicolumn{4}{|l|}{ Water temperature } \\
\hline$>19^{\circ}$ & 54 & $0.18(0.05,0.60)$ & 0.01 \\
\hline \multirow{2}{*}{\multicolumn{4}{|c|}{ Model 2. Drinking water storage $(n=91)$}} \\
\hline & & & \\
\hline \multicolumn{4}{|l|}{ Storage container } \\
\hline Container other than a kettle & 70 & $7.53(1.50,37.71)$ & 0.01 \\
\hline Kettle & 30 & Referent & - \\
\hline \multicolumn{4}{|l|}{ Water temperature } \\
\hline$\geq 30^{\circ} \mathrm{C}$ & 33 & $0.12(0.03,0.55)$ & 0.01 \\
\hline$<30^{\circ} \mathrm{C}$ & 67 & Referent & - \\
\hline \multicolumn{4}{|l|}{ House ownership } \\
\hline No legal title & 24 & $1.82(0.25,13.27)$ & 0.55 \\
\hline Legal title & 67 & $0.39(0.07,2.36)$ & 0.31 \\
\hline Rented/borrowed & 9 & Referent & - \\
\hline \multicolumn{4}{|c|}{ Model 3. Drinking water consumption $(n=64)$} \\
\hline \multicolumn{4}{|l|}{ Drinking cup } \\
\hline Wet & 25 & $7.15(1.61,31.71)$ & 0.01 \\
\hline Dry & 75 & Referent & - \\
\hline \multicolumn{4}{|l|}{ Water temperature } \\
\hline$>40^{\circ} \mathrm{C}$ & 30 & $0.10(0.02,0.59)$ & 0.01 \\
\hline$<40^{\circ} \mathrm{C}$ & 70 & Referent & - \\
\hline \multicolumn{4}{|l|}{ Cup storage } \\
\hline Covered & 44 & $0.20(0.05,0.78)$ & 0.02 \\
\hline Open & 56 & Referent & - \\
\hline
\end{tabular}

lecting utensils frequently carry fecal pathogens. Furthermore, the decline in water quality between source and household has been shown to be proportionately greater when source water is clean. ${ }^{28}$ Our data suggest that a similar circumstance exists within the home. We found that, in houses where principal stored water had residual free chlorine, $E$. coli counts increased significantly from the principal stored water stage to that of stored boiled drinking water.

Boiling failed to ensure the quality of the water people actually drank because of frequent contamination during subsequent storage. Almost one-third of our stored boiled water samples were fecally contaminated. In addition, the cost of boiling can be prohibitive. ${ }^{29,30}$ Boiling water costs about US $\$ 0.06$ per liter, and families in these communities typically boil $\approx 5 \mathrm{~L}$ of water per day. ${ }^{31,32}$ Households therefore spend approximately US\$110 per year, or $\approx 7 \%$ of a year's total earnings on boiling water. Furthermore, as our results show, this investment does not ensure the safety of drinking water.

For stored boiled drinking water, container type was the strongest predictor of fecal contamination. Water is safer from contamination in containers with a small opening than in those with a wide opening. . $^{8,10,12,33,34}$ Our data support this finding, with water in kettles having the lowest rate of contamination. In addition to being sterilized in the course of boiling, kettles may be a safer alternative to pots, which contribute to scalding of children. ${ }^{35}$ Practical considerations are likely to be paramount, however. Kettles are more expensive than pots and have a smaller capacity. In addition, water must be heated for cooking and bathing as well, so a scarcity of vessels could also necessitate the transfer of boiled water to a different container. Boiling is currently promoted for household-water treatment by multilateral agencies and humanitarian groups. Our evidence indicates the need for further protocols for the safe handling and storage of boiled water or, alternatively, promotion of chemical disinfection.

Finally, our data demonstrate that much of the contamina- 
TABLE 3

Geometric mean Escherichia coli counts (cfu/100 mL) in paired samples from in-house stages of water storage according to the presence of free active chlorine in principal water storage in peri-urban households of Lima, Peru

\begin{tabular}{|c|c|c|c|c|c|c|}
\hline \multirow[b]{2}{*}{$\begin{array}{l}\text { Free chlorine in } \\
\text { principal water storage }\end{array}$} & \multirow[b]{2}{*}{$N$} & \multicolumn{2}{|c|}{ Principal water storage containers } & \multicolumn{2}{|c|}{ Drinking water storage containers } & \multirow[b]{2}{*}{$P^{*}$} \\
\hline & & $\begin{array}{l}\text { Geometric } \\
\text { mean E. coli } \\
(\mathrm{cfu} / 100 \mathrm{~mL})\end{array}$ & $\underset{(\%)}{\text { Contaminated }}$ & $\begin{array}{l}\text { Geometric } \\
\text { mean E. coli } \\
\text { (cfu/100 mL) }\end{array}$ & $\underset{(\%)}{\text { Contaminated }}$ & \\
\hline Yes & 54 & 13 & 13 & 35 & 33 & 0.01 \\
\hline No & 30 & 19 & 53 & 89 & 30 & 0.78 \\
\hline
\end{tabular}

* By Wilcoxon matched-pairs signed-rank test comparing E. coli counts for the 2 containers by household; chlorine measure missing in 1 observation.

tion occurs in the drinking cup. Hands are likely to be the source of the fecal contamination found in swabs from the inside of glasses and in drinking cup water. We found elevated fecal bacteria counts on participants' hands, despite the short survival time of bacteria on skin; these bacteria could easily be transferred to dish-washing water and from there to drinking cups. ${ }^{36}$ Although no significant difference in bacterial counts was found in water samples before and after washing, the high level of contamination in water used to rinse the cups was striking. When cups were wet or moist prior to filling with water, the risk of fecal contamination was higher. Contaminated drinking glasses were implicated as a potential vehicle in an outbreak of hepatitis A, and contamination of utensils by rinse water has been shown to occur for E. coli, Salmonella, and Campylobacter. ${ }^{37,38}$ The same authors recommended higher wash- and rinse-water temperatures, but none of our respondents used hot water to wash their dishes, probably because of fuel costs. ${ }^{39}$ A more practical method to ensure clean drinking cups and other water vessels would be complete air-drying followed by storage in a covered container. Washing utensils with bleach could be an alternative, since heating water would increase costs. Hygiene improvement efforts should target dish-washing practices and other aspects of domestic water management, in addition to the standard promotion of hand washing after defecation or contact with excreta.

Our results improve our understanding of the relationship among personal hygiene, domestic hygiene, and water quality and demonstrate that fecal contamination of drinking water remains commonplace in the peri-urban communities of Lima, Peru. We offer the following recommendations based on known methods of improved water storage and point-ofuse treatment in the domestic domain ${ }^{40}: 1$ ) if source water is microbiologically clean, then use of containers with a narrow mouth, lid, and spigot would render boiling unnecessary; 2) in communities where safe sources do not exist and boiling is already practiced, education efforts should emphasize the use of kettles and other safe storage vessels for boiled drinking water; 3) point-of-use chemical disinfection of water is cheaper, safer, and more practical than boiling and, when combined with an adequate storage vessel, is an effective means of ensuring access to safe drinking water. ${ }^{41}$ Nevertheless, the best solution remains a connection in the home providing clean, chlorinated water; all else falls short.

Received January 22, 2007. Accepted for publication June 22, 2007.

Acknowledgments: We particularly thank Brigida Rosario Jimenez Hualpa for her time and knowledge of the community, and whose assistance made this study possible. We also thank Patricia Mónica Burgos Orejuela and Milagros Zavaleta Apéstegui; Margaret Kosek for advice during study design; Paula Maguiña for administrative support; and Rina Meza and NMRCD, Peru, for the use of their equipment. We are especially grateful to the residents of Las Pampas de San Juan de Miraflores for their time and cooperation.

Financial support: This study was funded by the TG35 Training Grant, "Tutorial in Tropical Health," financed by the Fogarty International Center (grant 5T35AI007646).

Authors' addresses: William E. Oswald, Lilia Cabrera, and Robert Gilman, Biomedical Research Unit, A.B. PRISMA, Av. Carlos Gonzales 251, Urb. Maranga, San Miguel, Lima 32, Peru, Telephone/ Fax: +51-1-464-0221, E-mail: william.oswald@jhsph.edu. Andrés G. Lescano, School of Public Health and Management, Universidad Peruana Cayetano Heredia, Av. Honorio Delgado 430, Urb. Ingeniería, S.M.P., Lima, Peru, Telephone: +51-1-562-3848, ext. 144, Fax: +51-1561-3042. Caryn Bern, Division of Parasitic Diseases, National Center for Zoonotic Vector-Borne and Enteric Diseases, Centers for Disease Control and Prevention, 4770 Buford Highway NE, Atlanta, GA 30341, Telephone: +1 770-488-7654, Fax: +1 770-488-7761. Maritza M. Calderon, Laboratorio de Investigación y Desarrollo, Universidad Peruana Cayetano Heredia, Av. Honorio Delgado 430, Urb. Ingeniería, S.M.P., Lima, Peru, Telephone: +51-1-483-2942.

Reprint requests: William E. Oswald, Biomedical Research Unit, A.B. PRISMA, Av. Carlos Gonzales 251, Urb. Maranga, San Miguel, Lima, Peru. E-mail: william.oswald@jhsph.edu.

\section{REFERENCES}

1. Kosek M, Bern C, Guerrant RL, 2003. The global burden of diarrhoeal disease, as estimated from studies published between 1992 and 2000. Bull World Health Organ 81: 197-204.

2. World Health Organization, 2004. Guidelines for Drinking-Water Quality. Geneva: World Health Organization.

3. van Zijl WJ, 1966. Studies on diarrhoeal diseases in seven countries by the WHO diarrhoeal diseases advisory team. Bull World Health Organ 35: 249-261.

4. El Attar L, Abdel Gawad A, Khairy AE, El Sebaie O, 1982. The sanitary condition of rural drinking water in a Nile Delta village. II. Bacterial contamination of drinking water in a Nile Delta village. J Hyg (Lond) 88: 63-67.

5. Han AM, Oo KN, Midorikawa Y, Shwe S, 1989. Contamination of drinking water during collection and storage. Trop Geogr Med 41: 138-140.

6. Swerdlow DL, Mintz ED, Rodriguez M, Tejada E, Ocampo C, Espejo L, Greene KD, Saldana W, Seminario L, Tauxe RV, Wells JG, Bean NH, Ries AA, Pollack M, Vertiz B, Blake PA, 1992. Waterborne transmission of epidemic cholera in Trujillo, Peru: lessons for a continent at risk. Lancet 340: 28-33.

7. Vanderslice J, Briscoe J, 1993. All coliforms are not created equal: a comparison of the effects of water source and in-house water contamination on infantile diarrheal disease. Water Resour Res 29: 1983-1995.

8. Jensen PK, Ensink JH, Jayasinghe G, van der Hoek W, Cairncross S, Dalsgaard A, 2002. Domestic transmission routes of pathogens: the problem of in-house contamination of drinking water during storage in developing countries. Trop Med Int Health 7: 604-609.

9. Clasen TF, Bastable A, 2003. Faecal contamination of drinking water during collection and household storage: the need to extend protection to the point of use. J Water Health 1: 109115 
10. Roberts L, Chartier Y, Chartier O, Malenga G, Toole M, Rodka $\mathrm{H}, 2001$. Keeping clean water clean in a Malawi refugee camp: a randomized intervention trial. Bull World Health Organ 79: 280-287.

11. Brick T, Primrose B, Chandrasekhar R, Roy S, Muliyil J, Kang G, 2004. Water contamination in urban south India: household storage practices and their implications for water safety and enteric infections. Int J Hyg Environ Health 207: 473-480.

12. Trevett AF, Carter R, Tyrrel S, 2004. Water quality deterioration: a study of household drinking water quality in rural Honduras. Int J Environ Health Res 14: 273-283.

13. Hoque BA, Hallman K, Levy J, Bouis H, Ali N, Khan F, Khanam S, Kabir M, Hossain S, Shah Alam M, 2006. Rural drinking water at supply and household levels: quality and management. Int J Hyg Environ Health 209: 451-460.

14. Checkley W, Gilman RH, Black RE, Epstein LD, Cabrera L, Sterling CR, Moulton LH, 2004. Effect of water and sanitation on childhood health in a poor Peruvian peri-urban community. Lancet 363: 112-118.

15. Trevett AF, Carter RC, Tyrrel SF, 2005. The importance of domestic water quality management in the context of faecal oral disease transmission. J Water Health 3: 259-270.

16. Gundry S, Wright J, Conroy R, 2004. A systematic review of the health outcomes related to household water quality in developing countries. J Water Health 2: 1-13.

17. Cairncross S, Blumenthal U, Kolsky P, Moraes L, Tayeh A, 1996. The public and domestic domains in the transmission of disease. Trop Med Int Health 1: 27-34.

18. Checkley W, Gilman RH, Black RE, Lescano AG, Cabrera L, Taylor DN, Moulton LH, 2002. Effects of nutritional status on diarrhea in Peruvian children. J Pediatr 140: 210-218.

19. Harvey SA, Winch PJ, Leontsini E, Torres Gayoso C, Lopez Romero S, Gilman RH, Oberhelman RA, 2003. Domestic poultry-raising practices in a Peruvian shantytown: implications for control of Campylobacter jejuni-associated diarrhea. Acta Trop 86: 41-54.

20. Hernandez LS, Winch PJ, Parker K, Gilman RH, 2006. Understandings of reproductive tract infections in a peri-urban pueblo joven in Lima, Peru. BMC Womens Health 6: 7.

21. Johnson MA, Smith H, Joseph P, Gilman RH, Bautista CT, Campos KJ, Cespedes M, Klatsky P, Vidal C, Terry H, Calderon MM, Coral C, Cabrera L, Parmar PS, Vinetz JM, 2004. Environmental exposure and leptospirosis, Peru. Emerg Infect Dis 10: 1016-1022.

22. Grant MA, 1997. A new membrane filtration medium for simultaneous detection and enumeration of Escherichia coli and total coliforms. Appl Environ Microbiol 63: 3526-3530.

23. Coll IJL, Torres MdMR, Fernández MC, 1999. Control e Higiene de los Alimentos. Madrid, Spain: McGraw-Hill.

24. ICMSF, 2000. Microorganismos de los Alimentos, 1: Su Significado y Métodos de Enumeración. Second edition. Zaragoza, Spain: Editorial Acribia.

25. Clasen T, Roberts I, Rabie T, Schmidt W, Cairncross S, 2006. Interventions to improve water quality for preventing diarrhoea. Cochrane Database Syst Rev 19: CD004794.

26. Feachem R, Burns E, Cairncross S, Cronin A, Cross P, Curtis D, Khalid Khan M, Lamb D, Southall H, 1978. Water, Health and Development: An Interdisciplinary Evaluation. London: TriMed Books, Ltd.
27. Quick RE, Venczel LV, Gonzalez O, Mintz ED, Highsmith AK, Espada A, Damiani E, Bean NH, De Hannover EH, Tauxe RV, 1996. Narrow-mouthed water storage vessels and in situ chlorination in a Bolivian community: a simple method to improve drinking water quality. Am J Trop Med Hyg 54: 511-516.

28. Wright J, Gundry S, Conroy R, 2004. Household drinking water in developing countries: a systematic review of microbiological contamination between source and point-of-use. Trop Med Int Health 9: 106-117.

29. World Health Organization, 2002. Managing Water in the Home: Accelerated Health Gains from Improved Water Supply. Geneva: World Health Organization.

30. Gilman RH, Skillicorn P, 1985. Boiling of drinking-water: can a fuel-scarce community afford it? Bull World Health Organ 63: 157-163.

31. Witt V, Reiff F, 1993. La Desinfección del Agua a Nivel Casero en Zonas Urbanas Marginales y Rurales. Serie Ambiental No. 13. Washington, D.C.: Pan American Health Organization.

32. Gilman RH, Marquis GS, Ventura G, Campos M, Spira W, Diaz F, 1993. Water cost and availability: key determinants of family hygiene in a Peruvian shantytown. Am J Public Health 83: $1554-1558$.

33. Deb BC, Sircar BK, Sengupta PG, De SP, Mondal SK, Gupta DN, Saha NC, Ghosh S, Mitra U, Pal SC, 1986. Studies on interventions to prevent $\mathrm{El}$ Tor cholera transmission in urban slums. Bull World Health Organ 64: 127-131.

34. Yeager BA, Lanata CF, Lazo F, Verastegui H, Black RE, 1991. Transmission factors and socioeconomic status as determinants of diarrhoeal incidence in Lima, Peru. J Diarrhoeal Dis Res 9: 186-193.

35. Delgado J, Ramirez-Cardich ME, Gilman RH, Lavarello R, Dahodwala N, Bazan A, Rodriguez V, Cama RI, Tovar M, Lescano A, 2002. Risk factors for burns in children: crowding, poverty, and poor maternal education. Inj Prev 8: 38-41.

36. Pinfold JV, 1990. Fæcal contamination of water and fingertiprinses as a method for evaluating the effect of low-cost water supply and sanitation activities on faeco-oral disease transmission. I. A case study in rural north-east Thailand. Epidemiol Infect 105: 363-375.

37. Sundkvist T, Hamilton GR, Hourihan BM, Hart IJ, 2000. Outbreak of hepatitis A spread by contaminated drinking glasses in a public house. Commun Dis Public Health 3: 60-62.

38. Mattick K, Durham K, Domingue G, Jorgensen F, Sen M, Schaffner DW, Humphrey T, 2003. The survival of foodborne pathogens during domestic washing-up and subsequent transfer onto washing-up sponges, kitchen surfaces and food. Int $J$ Food Microbiol 85: 213-226.

39. Mattick K, Durham K, Hendrix M, Slader J, Griffith C, Sen M, Humphrey T, 2003. The microbiological quality of washing-up water and the environment in domestic and commercial kitchens. J Appl Microbiol 94: 842-848.

40. Centers for Disease Control, 2006. SafeWater system (SWS). Atlanta, GA: CDC. Available from http://www.cdc.gov/ safewater/manual/sws_manual.pdf. Accessed August 15, 2007.

41. Mintz ED, Reiff FM, Tauxe RV, 1995. Safe water treatment and storage in the home. A practical new strategy to prevent waterborne disease. JAMA 273: 948-953. 